\title{
Hemoptysis caused by pulmonary sequestration in perforated appendicitis: A rare case report
}

\author{
Dario Tartaglia, M.D., Francesca Cascione, M.D., Matteo Modesti, M.D., Desiree Gianardi, M.D., \\ Rosilde Caputo, M.D., Christian Galatioto, M.D., Massimo Chiarugi, M.D.
}

Department of Emergency, University of Pisa, Pisa, Italy

\begin{abstract}
Pulmonary sequestration is a rare and usually asymptomatic congenital anomaly. Optimal management of this condition is still a subject of debate, including superiority of surgical resection or angiographic embolization of the aberrant arterial vessel. Presently described is rare case of a $5 \mathrm{I}$-year-old male who presented with hemoptysis related to pulmonary sequestration associated with acute right lower quadrant abdominal pain caused by perforated appendicitis.
\end{abstract}

Keywords: Perforated appendicitis; pulmonary sequestration; therapeutic strategy.

\section{INTRODUCTION}

Pulmonary sequestration, first described by Rokitansky in $186 \mathrm{I}$, is a rare congenital cystic malformation caused by lung tissue that is non-functioning and does not have normal communication with tracheobronchial vascular system, receiving blood flow instead directly from systemic vessels, such as the descending aorta. The abnormal tissue may be micro-cystic, containing many small cysts, or macro-cystic, containing several large cysts. There are 2 types of pulmonary sequestration: intralobar and extralobar. The first is confined to the lung, while the second involves accessory lung tissue completely enclosed in its own pleural sheath, usually situated between the lower lobe and the diaphragm.

This malformation is not a life-threatening condition, but it may present in different clinical ways, such as cardiovascular disease, long-term infection, bronchial cancer, and in very rare situations, hemoptysis caused by rupture of a blood vessel in the abnormal lung.

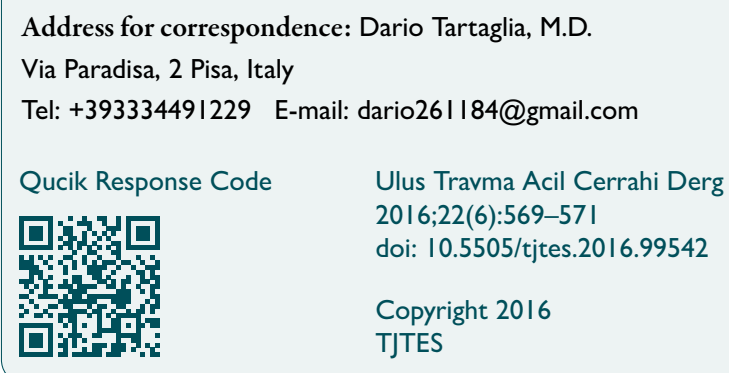

The most common treatment is surgical removal of the pulmonary sequestration.

Presently described is a case in which hemoptysis related to pulmonary sequestration presented simultaneously with acute abdomen caused by perforated appendicitis.

\section{CASE REPORT}

A 5 I-year-old male was admitted to the Emergency Department after onset of profuse hemoptysis associated with acute right lower quadrant abdominal pain and fever. Patient was hemodynamically stable. Laboratory exams revealed severe leukocytosis (white blood cell count: 18.490/mm3; neutrophil elastase: $89.1 \%$ ) and moderate increase in fibrinogen ( 944 $\mathrm{mg} / \mathrm{dL})$.

Contrast-enhanced computed tomography (CT) revealed pulmonary sequestration of the left inferior pulmonary lobe fed by an anomalous arterial vessel originating from the celiac trunk. Furthermore, large area of inflammation in the right abdomen with air bubbles was observed, compatible with complicated severe acute appendicitis (Figs. I, 2).

Management plan was to achieve control of hemoptysis first, followed by surgical management of the abdominal condition. Accordingly, the patient underwent selective artery angiography, which confirmed presence of abnormal vessel originating from the celiac trunk and feeding the sequestered pulmonary lobe. Superselective angioembolization of the feeding vessel with $7 \mathrm{~mm}$ vascular plug was performed. The procedure was completed without complications (Fig. 3). 


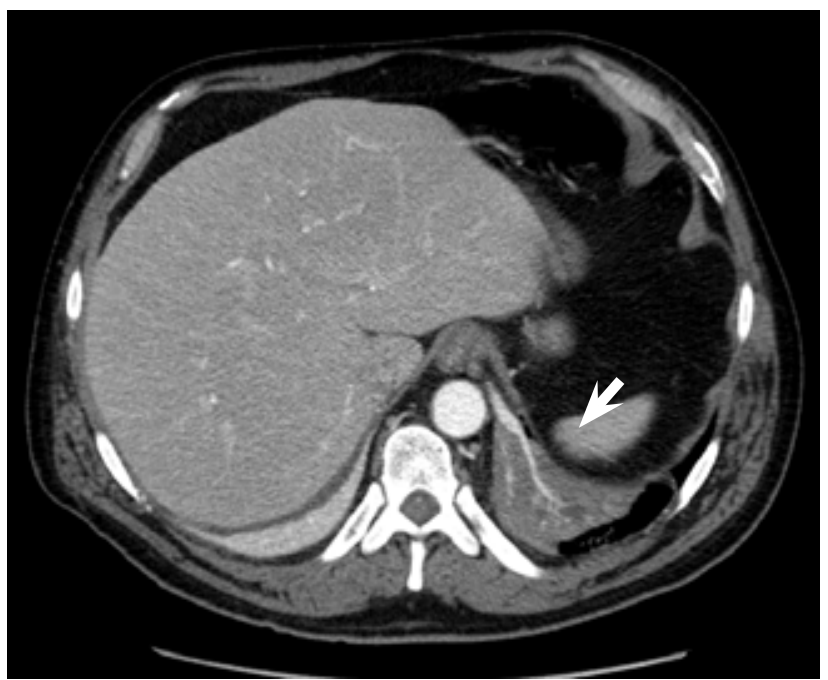

Figure 1. Contrast computed tomography scan. Pulmonary sequestration at the base of left inferior lobe of the lung is perfused by large arterial vessel originating from the celiac trunk (arrow).

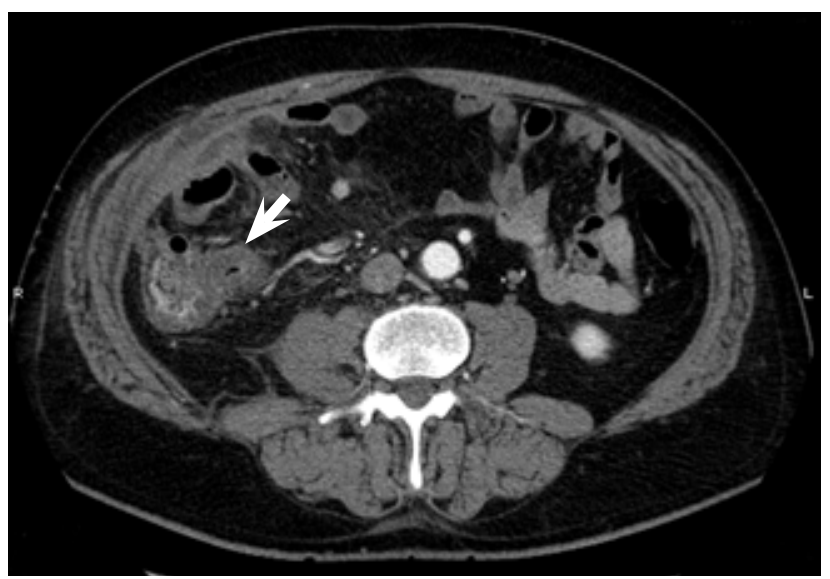

Figure 2. Computed tomography scan of the abdomen showing fluid collection and minute gas bubbles around the cecum (arrow).

Following percutaneous procedure, the patient underwent laparoscopy. Exploration of the abdominal cavity showed adhesions among the cecum, the ileum and the anterior abdominal wall, which were cautiously lysed. Voluminous appendicular abscess was drained and samples were sent for cultures. Perforated gangrenous appendicitis was identified (Fig. 4). Appendectomy was then performed.

Postoperatively, the patient received broad-spectrum antibiotic therapy with ciprofloxacin and metronidazole. Bacterial culture results were positive for Enterococcus avium and Escherichia coli.

Episodes of mild fever occurred during first days of the course, but gradually resolved; follow-up CT scan of the chest did not show any infective complication of the embolization procedure.

The patient was discharged in good condition on postoperative day 12 .

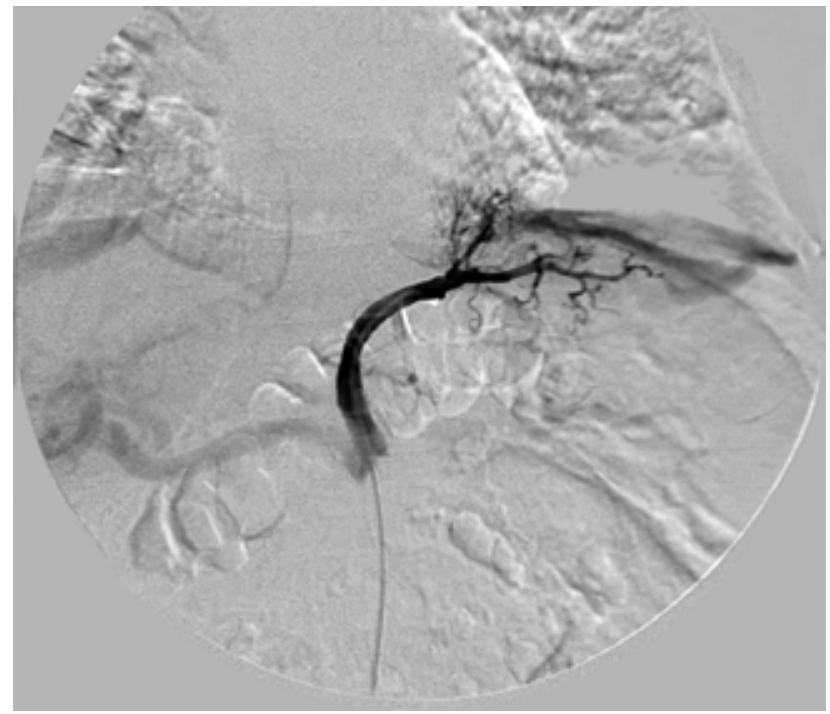

Figure 3. Selective angiography of the aberrant arterial vessel tributary to the sequestrated lobe before embolization.

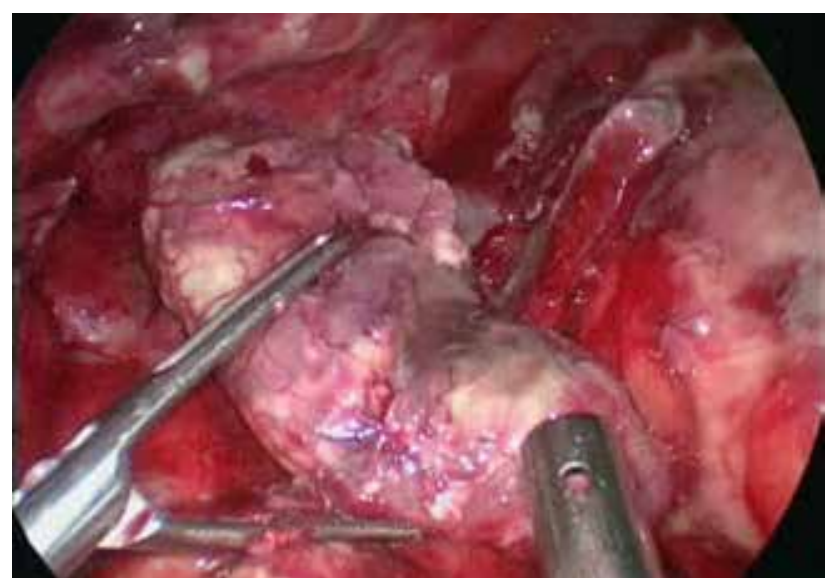

Figure 4. Perforated gangrenous appendicitis as seen at laparoscopy.

\section{DISCUSSION}

Pulmonary sequestration is a rare congenital malformation with an incidence of $0.15 \%$ to $1.8 \%$ of all pulmonary malformations. ${ }^{[1,2]}$ According to Pryce et al., ${ }^{[3]}$ this abnormality is classified in 2 types: type $I$ is characterized by an isolated systemic arterial supply to normal lung, while type 2 has dual supply from systemic and pulmonary vascularization.

Surgical resection of pulmonary sequestration, usually performed through postero-lateral thoracotomy, has been considered the safest and most effective method of treatment for a long time. Recently, Tamura et al. reported on efficiency and safety of video-assisted thoracoscopy surgery for treatment of extra-lobar sequestration and found less postoperative pain and a faster recovery in comparison with conventional surgery. ${ }^{[4]}$ Angiographic embolization has been proposed as a successful alternative to surgery. ${ }^{[5]}$ Thus far, however, investigations comparing the results of embolization with those of surgical resection are lacking. ${ }^{[6]}$ Angio- 
graphic embolization has the advantage of providing means for effective and immediate control of bleeding in massive hemoptysis. It is also believed to have a role in preventing recurrent episodes of hemoptysis and reducing risk of bleeding during surgery in patients with severe heart failure. When employed as definitive means of treatment, angioembolization was associated with lower risk of morbidities than thoracotomy. ${ }^{[9-11]}$

On the other hand, Diks et al. reported that angiographic embolization could not achieve complete control of main complications of pulmonary sequestration: pleural pain, ischemic infarction, and abscess formation. For this reason, they maintained that surgical resection is still the most effective and definitive therapeutic strategy for this kind of lung malformation. ${ }^{[12]}$

Presently described is a case of symptomatic pulmonary sequestration and gangrenous acute appendicitis. To our knowledge, this is the first case in the literature with simultaneous presentation of these 2 diseases. Therapeutic management was undertaken with multidisciplinary consensus of chest surgeons, general surgeons, and radiologists. Initial therapeutic strategy consisted of performing angiographic embolization of the aberrant arterial vessel from the celiac trunk, followed by laparoscopic appendectomy. Both of these procedures were performed without significant complications, despite some concern about risk of superinfection of the embolized pulmonary tissue from bacteria responsible for the abdominal infection in the bloodstream. At the time of writing, no thoracotomy procedure is planned to resect the sequestration; however, the patient has been provided with radiological follow-up of chest.

The present case provides a therapeutic strategy that might be selected in case of contemporaneous presence of symptomatic pulmonary sequestration and perforated appendicitis.

\section{Consent}

Written informed consent was obtained from the patient for publication of this case report and accompanying images. A copy of the written consent is available for review from the editor-in-chief of this journal.

\section{Conflict of interest: None declared.}

\section{REFERENCES}

1. Corbett HJ, Humphrey GM. Pulmonary sequestration. Paediatr Respir Rev 2004;5:59-68. Crossref

2. Kabnick EM, Adler L, Susin M, Helfgott A, Alexander LL, Tafreshi M. Pulmonary sequestration. J Natl Med Assoc 1984;76:907-8, 911-2.

3. Pryce DM. Lower accessory pulmonary artery with intralobar sequestration of lung; a report of seven cases. J Pathol Bacteriol 1946;58:457-67.

4. Tamura M, Shimizu Y, Hashizume Y. Single-incision video-assisted thoracic resection for extrapulmonary sequestration: a case report. J Cardiothorac Surg 2014;9:22. Crossref

5. Kim JH, Kim SS, Ha KS, Bae J, Park Y. Anomalous arterial supply to normal Basal segment of the right lower lobe: endovascular treatment with the amplatzer vascular plug. Tuberc Respir Dis (Seoul) 2014;76:295-8.

6. Seok JP, Kim YJ, Cho HM, Ryu HY. A rare case of bilateral pulmonary sequestration managed with embolization and surgical resection in a patient. Korean J Thorac Cardiovasc Surg 2013;46:475-7. Crossref

7. Gümüştaş S, Akça A, Ciftçi E, Topçu S, Akgül AG. A minimal invasive surgical alternative to aberrant systemic arterial supply: Coil embolization. Interv Med Appl Sci 2013;5:34-8. Crossref

8. Bhalla AS, Gupta P, Mukund A, Kumar A, Gupta M. Anomalous systemic artery to a normal lung: a rare cause of hemoptysis in adults. Oman Med J 2012;27:319-22. Crossref

9. Marine LM, Valdes FE, Mertens RM, Bergoeing MR, Kramer A. Endovascular treatment of symptomatic pulmonary sequestration. Ann Vasc Surg 2011;25:696.e11-5. Crossref

10. Geyik S, Yavuz K, Keller FS. Unusual systemic artery to pulmonary artery malformation without evidence of systemic disease, trauma or surgery. Cardiovasc Intervent Radiol 2006;29:897-901. Crossref

11. Saida T, Ninomiya H, Hojo F, Nakayama M, Yamauchi T, Saida Y. Systemic arterial supply to the normal basal segments of the left lower lobe treated by coil embolization, with long-term follow-up. Radiat Med 2006;24:365-8, Crossref

12. Diks J, Schütte PR, Cheung D, Schnater JM. Treatment of pulmonary sequestrations by means of endovascular embolization: future or fashion? Case Rep Med 2011;2011:173918.

\section{OLGU SUNUMU - ÖZET}

Perfore apandisitte pulmoner sekestrasyonun neden olduğu hemoptizi: Seyrek görülen bir olgunun raporu

Dr. Dario Tartaglia, Dr. Francesca Cascione, Dr. Matteo Modesti, Dr. Desiree Gianardi, Dr. Rosilde Caputo, Dr. Christian Galatioto, Dr. Massimo Chiarugi

Pisa Üniversitesi, Acil Tıp Anabilim Dalı, Pisa-italya

Pulmoner sekestrasyon seyrek görülen ve genellikle semptomsuz bir doğuştan anomalidir. Bu rahatsızlığın optimal tedavisi hâlâ tartışmalı olup cer rahi rezeksiyonları veya aberan arterin anjiyografik embolizasyonunu içerir. Perfore apandisitin neden olduğu akut sağ alt kadran karın ağrııının eşlik ettiği pulmoner sekestrasyonla ilişkili hemoptiziyle gelen 5 I yaşında nadir görülen bir erkek olguyu sunuyoruz.

Anahtar sözcükler: Perfore apandisit tedavi stratejisi; pulmoner sekestrasyon.

Ulus Travma Acil Cerrahi Derg 2016;22(6):569-57| doi: 10.5505/tjtes.2016.99542 